\title{
Carga inmediata con implantes en maxilar superior
}

\section{Immediate loading of implants in the maxilla}

\author{
F. Monje Gil', C. Moreno García², H. Serrano Gil2, O. Maestre2, A.J. Morillo Sánchez³, J. Mateo Arias ${ }^{3}$, \\ L. Ruiz Laza3, P. Quiros Álvarez³, D. Manzano Solo de Zaldivar ${ }^{3}$
}

Resumen: La carga inmediata en la mandíbula se ha incorporado a la práctica clínica en primer lugar y, por las características del hueso, se realiza de forma protocolizada. Sin embargo, en el maxilar superior no hay evidencia científica para realizarlo de forma cotidiana. Las razones son debidas a que el maxilar superior, en general, alberga una masa ósea de menor densidad. Por otro lado, en el maxilar superior pueden coexistir diferentes densidades óseas (según la clasificación de Misch) en el mismo individuo. Además, por las características anatómicas del maxilar superior (reabsorción labiopalatina) el alineamiento axial es asumible pero, sin embargo, el paralelismo de los implantes es difícil. ${ }^{16,17}$

El objetivo del presente trabajo es analizar la información científica de la que disponemos para confirmar si es posible la carga inmediata sobre el maxilar superior. Para ello estudiaremos varios aspectos de la carga inmediata en el maxilar superior:

- Sobredentaduras

- Prótesis fija completa

- Prótesis parcial fija

- Prótesis unitaria fija

- Requerimientos protésicos

- Contraindicaciones

Palabras clave: Carga inmediata; Implantes dentales.

Recibido: 03.01.07

Aceptado: 29.01 .07

\author{
1 Jefe de Servicio \\ 2 Médico Residente \\ 3 Médico Adjunto \\ Servicio de Cirugía Oral y Maxilofacial. \\ Hospital Universitario Infanta Cristina, Badajoz, España.
}

\begin{abstract}
Immediate loading in the mandible has been introduced into clinical practice taking first place and, and because of the characteristics of the bone, this is carried out following a protocol. However, in the maxilla there is no scientific evidence for routinely carrying this out. This is because the maxilla, in general, has a lower bone mass density. Moreover, in the maxilla various densities may coexist (according to Misch's classification) in the same individual. In addition, given the anatomic characteristics of the maxilla (lip and palate resorption), axial alignment can be carried out, but implant parallelism is difficult. ${ }^{16,17}$

The aim of this paper is to analyze the scientific information that we have at our disposal in order to confirm whether immediate loading in the maxilla is possible. For this we will study various aspects of immediate loading in the maxilla:

- Overdentures

- Fixed complete prostheses

- Fixed partial prostheses

- Fixed single tooth prostheses

- Prosthetic requirements

- Contraindications
\end{abstract}

Key words: Inmediate loading; Dental implants. 


\section{Introducción}

En el año 1979 Lederman, ${ }^{1}$ publicó los primeros estudios sobre carga inmediata en implantes dentales. Ferulizaba cuatro implantes intermentonianos con una barra y colocaba una sobredentadura en el mismo día de la intervención. Sin embargo, este tratamiento no se realizaba de forma protocolizada. De hecho, en 1985 Branemark, ${ }^{2}$ definía la oseointegración como "la conexión directa, funcional y estructural, entre el hueso vital y la superficie del implante". Los protocolos implantológicos iniciales, ${ }^{3,4}$ contraindicaban la carga inmediata pues consideraba siempre necesario posponer la carga de los implantes dentales durante un periodo que oscilaba entre los 3 y 6 meses posteriores a la colocación de los mismos. Afirmaban que el trauma quirúrgico junto con la carga inmediata del implante, provocarían el desarrollo de un tejido cicatricial en la interfase hueso-implante. ${ }^{2}$ De hecho, estudios en la literatura ortopédica han demostrado el papel de la macromoción en la diferenciación de tejido alrededor de implantes endo-óseos colocados en la metáfisis de huesos. En los mismos, el macromovimiento induce tejido fibroso que se interpone entre la superficie del implante y el hueso. ${ }^{5}$ Por ello, la estabilidad primaria y posponer la carga aproximadamente de tres a seis meses ha sido considerado durante años "conditio sine qua non" para conseguir la oseointegración de los implantes dentales.

Estudios experimentales posteriores, como los realizados por Sagara, ${ }^{6}$ Zubery, ${ }^{7}$ Piatelli, ${ }^{8}$ Romanos, ${ }^{9}$ invalidarían esta afirmación. Nkenke y cols. ${ }^{10}$ utilizando cerdos $y$, tras 6 meses de seguimiento, analizaron los resultados de los parámetros histomorfométricos valorados (contacto hueso-implante y área de hueso periimplantario) en implantes con carga inmediata a nivel de maxilar superior. Estos fueron similares a los obtenidos con implantes cargados tras un periodo libre de carga superior a 5 meses.

Micromovimientos mayores de 150 micras se consideran excesivos y perjudiciales para la oseointegración. Pero por el contrario, micromovimientos menores de 50 micras son bien tolerados. Por tanto, el umbral crítico, dependiendo de la morfología del implante y de su superficie, estaría entre 50 y 150 micras. ${ }^{11-15}$

En la actualidad, al referirnos a carga inmediata hablamos de aquella situación en la que una vez insertada la fijación en el hueso, se realizan las prótesis implantosoportadas, de forma que el implante recibe carga funcional en un periodo de tiempo inferior a 48 horas a partir de la colocación de los implantes. En la restauración inmediata, también denominada carga inmediata no funcional, la prótesis se colocaría en el mismo periodo de tiempo pero fuera de oclusión. La carga convencional sería aquella en la que se espera entre 3 a 6 meses para cargar los implantes y hablaríamos de carga precoz cuando la carga de los mismos se efectúa entre 48 horas y 3 meses tras la colocación de los implantes. ${ }^{5}$ Desde hace mucho tiempo la carga inmediata tiene interés porque acorta los tiempos de tratamiento y evita la provisionalidad. El refinamiento de los protocolos clínicos, la aplicación de unos principios biomecánicos adecuados, las mejoras en el diseño del implante y el desarrollo de nuevas superficies ha dado lugar a la introducción de esta modalidad.

\section{Introduction}

In the year 1979, Lederman' published the first studies on the immediate loading of dental implants. Four bar-splinted chin implants were placed and an overdenture was placed the same day of the intervention. However, this treatment was not carried out following a protocol. In fact in 1985, Branemark ${ }^{2}$ defined osseointegration as the direct, functional and structural connection between vital bone and the surface of the implant. The initial implantological protocols $s^{3,4}$ contraindicated immediate loading during a period that varied between 3 and 6 months after placement. They affirmed that surgical trauma, together with the immediate loading of the implant, would led to scar tissue developing in the bone-implant interphase. ${ }^{2}$ In fact, studies in the orthopedic literature have shown the role of macromotion in the differentiation of tissue around endosseous implants placed in metaphyseal bones. Here, macromotion led to fibrous tissue being interposed between the implant and bone..$^{5}$ As a result, primary stability and postponing the load approximately three to six months has been considered for years "conditio sine qua non" for achieving osseointegration of dental implants.

Later experimental studies, such as those carried out by Sagara, ${ }^{6}$ Zubery, $^{7}$ Piatelli, ${ }^{8}$ and Romanos ${ }^{9}$ invalidated this affirmation. Nkenke and cols. ${ }^{10}$ who used minipigs, analyzed after a 6 month follow-up, the results of the histomorphometric parameters assessed (bone-implant contact and peri-implant bone area) in immediate loading implants in the maxilla. These were similar to those obtained with implants that were loaded after a load-free period of over 5 months.

Micromovements of over 150 micras are considered excessive and harmful to osseointegration. But, on the other hand, micromovements of less than 50 micras are well-tolerated. Therefore, the critical threshold, depending on the morphology of the implant, would be between 50 and 150 micras. ${ }^{11-15}$

Currently we refer to immediate loading as placing an implant-supported prosthesis, once the fixation has been inserted into the bone, in such as way that the implant receives a functional load in less than 48 hours as from the placement of the implants. In immediate restoration, also known as immediate non-functional loading, the prosthesis is placed in the same period of time but out of occlusion. In conventional loading there is a delay of 3 to 6 months before the implants are loaded. We would refer to early loading when the implants are loaded between 48 hours and 3 months after placement. ${ }^{5}$ Immediate loading has been of interest for some time because treatment times are shortened and provisionalization is avoided. The refinement of clinical protocols, the application of adequate biomechanical principles, the improvement in implant designs and the development of new surfaces, has given rise to the introduction of this modality. 


\section{Sobredentaduras}

No hemos encontrado artículos sobre carga inmediata de sobredentaduras implantosoportadas en maxilar superior edéntulo. ${ }^{18}$

\section{Prótesis completa fija}

En 1997 Tarnow $^{19}$ describe un protocolo de carga inmediata sobre maxilar superior edéntulo con objeto de obtener la estabilización de implantes intra e interarco. Este mismo autor y otros, ${ }^{19-}$ 21 señalan factores clínicos que han de ser considerados a la hora de plantearse la realización de carga inmediata. Se consideran factores que pueden posibilitar acometer la carga inmediata en el maxilar superior:

- La estabilidad primaria del implante

- La adecuada ferulización de los mismos

- Restauraciones provisionales que promuevan la ferulización de los implantes y reduzcan el control de las cargas mecánicas aplicadas a los implantes

- La prevención del movimiento de restauraciones provisionales durante el periodo de cicatrización

- El trabajo en equipo si en la carga inmediata colaboran diversos profesionales (cirujano, protesista, protésico, periodoncista, ortodoncista y anestesista).

No hay que olvidar que los objetivos que deben regir la elección de carga inmediata son los mismos que la carga convencional: la planificación y diseño completo del plan de tratamiento, valoración de las expectativas estéticas del paciente, valoración de la calidad, cantidad y morfología de los tejidos blandos y la verificación de patología ósea en la región de los dientes adyacentes o de los dientes a extraer así como del tejido óseo del paciente.

Desde el punto de vista quirúrgico, es importante tener en cuenta algunas consideraciones como:22

- La selección, posición y distribución de los implantes deben ser guiadas por un plan restaurador completo que tenga en cuenta no solo el momento de la carga.

- Deben utilizarse férulas quirúrgicas que indicarán el plan protésico y éstas deben ser estables y perfectamente adaptadas al contorno alveolar y palatino. Han de ser rígidas, dar un adecuado acceso y visibilidad, así como guiar la colocación del implante en tres dimensiones. ${ }^{54}$

- Intentar minimizar los riesgos biomecánicos.

- Un adecuado número de implantes han de ser posicionados para facilitar la ferulización y los posibles efectos de la micromoción. La estabilidad primaria de los implantes debe conseguirse. Esto puede ser posible mediante la selección de los pacientes que presenten adecuado hueso en cantidad y calidad. Debe utilizarse un implante con una superficie determinada y adecuada dimensión y una técnica clínica adecuada para mantener el contacto entre implante y hueso. ${ }^{23}$ En cuanto a la técnica quirúrgica a realizar, se han presentado distintas modificaciones: ${ }^{24}$

- Reducir todo lo posible el traumatismo a nivel del lugar de osteotomía o si éste se lleva a cabo que sea sólo a nivel de zonas de hueso denso.
Immediate loading in the mandible has been introduced into clinical practice taking first place and, and because of the characteristics of the bone, this is carried out following a protocol. However, in the maxilla there is no scientific evidence for routinely carrying this out. This is because the maxilla, in general, has a lower bone mass density. Moreover, in the maxilla various densities may coexist (according to Misch's classification) in the same individual. In addition, given the anatomic characteristics of the maxilla (lip and palate resorption), axial alignment can be carried out, but implant parallelism is difficult. 16,17

The aim of this paper is to analyze the scientific information that we have at our disposal in order to confirm whether immediate loading in the maxilla is possible. For this we will study various aspects of immediate loading in the maxilla:

- Overdentures

- Fixed complete prostheses

- Fixed partial prostheses

- Fixed single tooth prostheses

- Prosthetic requirements

- Contraindications

\section{Overdentures}

We have not been able to find any articles on the immediate loading of implant-supported overdentures in the edentulous maxilla. ${ }^{18}$

\section{Fixed complete prostheses}

In 1997 Tarnow $^{19}$ described an immediate loading protocol for the edentulous maxilla with the aim of obtaining stabilization of intra- and interarch implants. This same author and others $19-21$ pointed out the clinical factors that have to be considered when carrying out immediate loading. Factors that can make immediate loading in the maxilla possible are considered to be the following:

- Primary implant stability.

- Adequate implant splinting.

- Provisional restorations that favor implant splinting and that reduce the control of the mechanical load applied on the implants.

- Movement prevention of provisional restorations during the healing period.

- Team work if in the immediate loading procedure various professionals collaborate (surgeon, prosthetist, prosthetics maker, periodontist, orthodontist and anesthetist). It should not be forgotten that the objectives that should determine choosing immediate loading are the same as those for conventional loading: planning and complete design of the treatment strategy, evaluation of the aesthetic expectancies of the patient, evaluation of the quality, quan- 
Tabla 1. Estudios prospectivos en carga inmediata en maxilar superior edéntulo

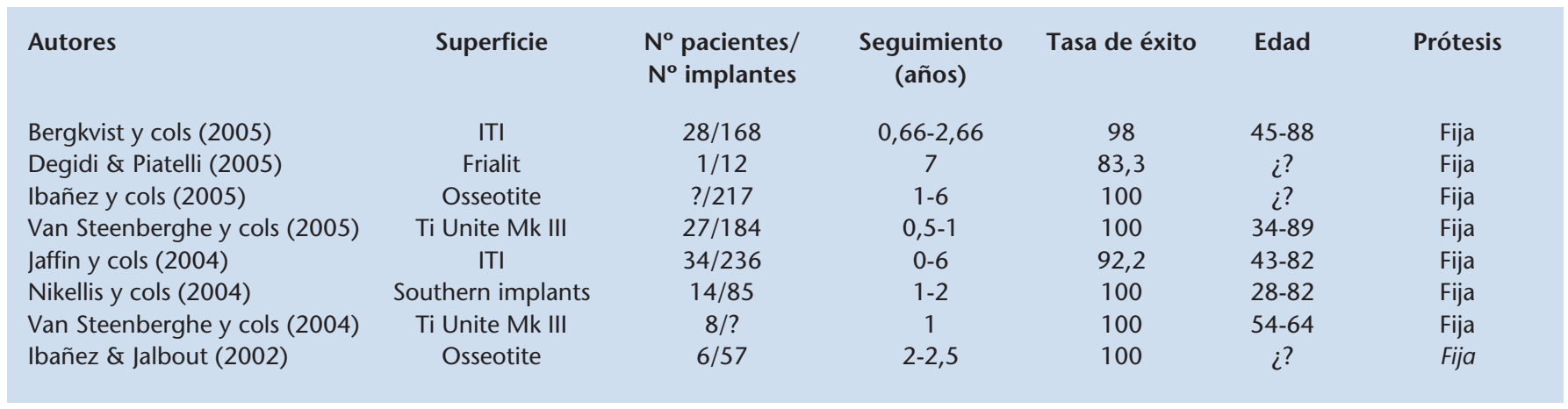

Table 1. Prospective studies in immediate loading in the edentulous maxilla

\begin{tabular}{|c|c|c|c|c|c|c|}
\hline Authors & Surface & $\begin{array}{l}N^{\circ} \text { patients/ } \\
N^{\circ} \text { implants }\end{array}$ & $\begin{array}{l}\text { Follow-up } \\
\text { (years) }\end{array}$ & Success rate & Age & Prosthesis \\
\hline Bergkvist \& cols (2005) & $I T I$ & $28 / 168$ & $0,66-2,66$ & 98 & $45-88$ & Fixed \\
\hline Degidi \& Piatelli (2005) & Frialit & $1 / 12$ & 7 & 83,3 & ¿? & Fixed \\
\hline Ibañez \& cols (2005) & Osseotite & $? / 217$ & $1-6$ & 100 & ¿? & Fixed \\
\hline Van Steenberghe \& cols (2005) & Ti Unite Mk III & $27 / 184$ & $0,5-1$ & 100 & $34-89$ & Fixed \\
\hline Jaffin \& cols (2004) & $I T I$ & $34 / 236$ & $0-6$ & 92,2 & $43-82$ & Fixed \\
\hline Nikellis \& cols (2004) & Southern implants & $14 / 85$ & $1-2$ & 100 & $28-82$ & Fixed \\
\hline Van Steenberghe \& cols (2004) & Ti Unite Mk III & $8 / ?$ & 1 & 100 & $54-64$ & Fixed \\
\hline Ibañez \& Jalbout (2002) & Osseotite & $6 / 57$ & $2-2,5$ & 100 & ¿? & Fixed \\
\hline
\end{tabular}

- Evitar el avellanado.

- Intentar conseguir una estabilización bicortical.

- Utilizar fresas más delgadas de lo estipulado para la carga convencional para conseguir mayor estabilidad primaria.

Asi, en los artículos que se estudiaron (Tabla 1) 25-30 abarcaban la rehabilitación de 113 arcadas superiores (959 implantes) con un índice medio de éxito de 98,24\%.

Existen variables que son importantes considerar a la hora de hablar de carga inmediata en el maxilar superior.

\section{Condiciones generales}

Desde el punto de vista de estado general del paciente se discuten enfermedades generales como la diabetes o el tabaquismo. Algunos autores, ${ }^{31-33}$ consideran a los pacientes diabéticos como una contraindicación para la realización de carga inmediata. Sin embargo, otros, ${ }^{23,27}$ excluyen de sus protocolos sólo a aquellos que no llevan un adecuado control de su enfermedad.

El tabaquismo es considerado una contraindicación para la inclusión en protocolos de carga inmediata. ${ }^{34-37}$ Sin embargo, algunos autores, ${ }^{38,39}$ sólo excluyen a aquellos que son grandes fumadores (más de 10 cigarrillos por día).

\section{Alvéolos postextracción}

Los eventos que ocurren a nivel del alvéolo post - extracción, han sido identificados mediante el examen de material histológico animal. ${ }^{40-42}$ La primera fase consiste en la formación del coágulo con células procedentes de la circulación sanguínea. En la segunda

tity and morphology of soft tissue and verification of bone pathology in the area of the adjacent teeth or of the teeth to be extracted, as well as the patient's bone tissue.

From the surgical point of view, it is important to bear in mind certain considerations, such as: 22

- The choice, position and distribution of the implants should follow a complete restoration plan that takes into consideration not just the moment of loading.

- Surgical splints should be used to indicate the prosthetic plan and these should be stable and perfectly adapted to the alveolar area and palate. They should be rigid, and they should ensure adequate access and visibility. They should also be able to guide three dimensional implant placement. ${ }^{54}$

- Attempting to minimize biomechanical risks.

- An adequate number of implants have to be positioned in order to facilitate splinting and the possible effects of micromotion.

Primary stability of the implants should be achieved. This may be possible by choosing patients that have adequate bone in terms of quantity and quality. An implant with a particular surface and adequate dimensions, and an adequate clinical technique should be used to maintain the contact between the implant and bone. ${ }^{23}$ With regard to the surgical technique to be carried out, different modifications have been put forward:24

- Reducing as much as possible the trauma to the osteotomy area, and if this is carried out it should only be carried out in areas with dense bone. 
fase, es decir a los 4 ó 5 días, el tejido de granulación recubre todo el alvéolo. A partir de los 15 días, el tejido conectivo sustituye por completo al tejido de granulación y en torno a las 6 semanas se produce la calcificación del tejido osteoide y el hueso trabecular cubre por completo el alvéolo. En una última fase se produce el cierre epitelial completo de la zona de extracción. La máxima actividad osteoblástica, así como la proliferación celular y de elementos del tejido conectivo, ocurre entre las 4-6 semanas después de la extracción. A partir de la octava semana el proceso osteogénico comienza a disminuir. ${ }^{36}$ Por lo tanto, entre 4 y 8 semanas, parece ser el periodo óptimo para colocar el implante y conseguir un adecuado volumen de tejidos blandos y la menor pérdida posible de volumen óseo en casos de infección activa. ${ }^{43}$

La colocación de implantes de forma inmediata tras la extracción, puede prevenir la pérdida ósea que sigue a la pérdida dentaria, evitando en ocasiones técnicas más complejas para restaurar el futuro lecho del implante. Así mismo, la implantación inmediata permite acortar el tiempo de tratamiento, lo que constituye uno de los objetivos actuales. Aproximadamente 5-7 milímetros de la reabsorción horizontal o bucolingual del maxilar, que representa en torno al 50\% de la situación de partida, ocurre a los 6-12 meses tras la extracción dentaria. Un reabsorción apicoronal o vertical de 2 a $4 \mathrm{~mm}$ acompaña a los cambios horizontales. ${ }^{44,45}$ Los cambios apicoronales son más evidentes en lugares de exodoncias múltiples. ${ }^{45-47}$ Estos cambios son ligeramente más grandes en la región molar que en la región premolar, y en la mandíbula en comparación al maxilar superior. Una gran variedad de factores pueden influir en los cambios dimensionales del hueso tras la extracción dentaria. Podemos incluir factores sistémicos, en relación con la salud previa del paciente y hábitos como el tabaquismo. Dentro de los factores locales, podemos incluir las causas de la extracción, el número y proximidad de dientes extraidos y la situación del alvéolo antes y después de la extracción dentaria. ${ }^{43} \mathrm{El}$ seguimiento durante periodos de tiempo comprendidos entre 1 y 4 años, no ha mostrado diferencias significativas, en cuanto a cambios radiográficos en los niveles de hueso, entre lugares de implantación donde se realizó carga inmediata, frente a otros en los que se realizó carga convencional. ${ }^{48-52}$ Los alvéolos con defectos de dehiscencia pueden carecer de potencial para la completa regeneración ósea, y el riesgo de complicaciones a largo plazo puede verse aumentado con la realización de carga inmediata sobre implantes. ${ }^{53}$

Ha sido demostrado por varios estudios, que las tasas de supervivencia de implantes inmediatos tras exodoncia de dientes con fracturas radiculares, perforaciones o con una combinación de problemas endodónticos y periodontales, es similar a los implantes colocados en zonas ya cicatrizadas. ${ }^{54-58}$ Como siempre, los implantes colocados en sitios donde el diente ha sido afectado por periodontitis crónica, se han asociado con tasas de fracaso ligeramente más elevadas. ${ }^{59,60}$ Cuando la colocación del implante es demorada tras la extracción dentaria, los tejidos blandos cicatrizan y ganan volumen, lo que permitirá en un futuro adaptar colgajos, que ayuden a conseguir buenos resultados estéticos. Por lo tanto, el tiempo que pase entre la extracción dentaria y la colocación del implante, aportará ventajas en cuanto a la mayor obtención de tejidos blandos, pero con el riesgo de pérdida ósea debido a la reabsorción. ${ }^{43}$
- Countersinking should be avoided.

- Bicortical stabilization should be attempted.

- Finer drills should be used than those stipulated for conventional loading in order to achieve greater primary stability.

In the articles studied (Table 1) 25-30 the rehabilitation of 113 upper arches was undertaken (959 implants) with a mean success rate of $98.24 \%$.

There are variables that are important to keep in mind when discussing immediate loading in the maxilla.

\section{General conditions}

From the point of view of the general health of the patient, general conditions such as diabetes or smoking are debated. Some authors ${ }^{31-33}$ consider diabetic patients as a contraindication for carrying out immediate loading. However, others 23,27 exclude from their protocols only those that do not have adequate control of their condition.

Smoking is considered a contraindication in immediate loading protocols.34-37 However, other authors ${ }^{38,39}$ only exclude those that are heavy smokers (more than 10 cigarettes a day).

\section{Post-extraction sockets}

What occurs to post-extraction sockets has been identified by means of histological examination of animal material. ${ }^{00-42}$ The first phase consists in clot formation with blood circulation cells. In the second phase, that is to say on day 4 or 5, granulation tissue covers the socket completely. As from day 15, the connective tissue will completely substitute the granulation tissue and, at around 6 weeks, calcification of the osteoid tissue is produced and the trabecular bone will completely cover the socket. In the last phase, complete epithelial closure will take place in the extraction site. Maximum osteoblastic activity, as well as the proliferation of cells and connective tissue elements takes place 4-6 weeks after extraction. From week 8, the osteogenic process starts slowing down. ${ }^{36}$ Therefore, the best time for implant placement seems to be between week 4 and 8 . This is also the best period for achieving adequate soft-tissue volume and the least loss of bone volume in cases of active infection. ${ }^{43}$

Immediate-type placement of implants, following extraction, can prevent bone loss that occurs after tooth loss, avoiding on occasions more complex techniques for restoring the future implant bed. Thus, immediate implants permit shortening treatment time, which is currently one of the objectives. Approximately 5-7 millimeters of horizontal or buccolingual resorption of the maxilla, that represents around $50 \%$ of the starting point, occurs at 6-12 months after dental extraction. An apicoronal, or vertical resorption, of 2 to $4 \mathrm{~mm}$ accompanies the horizontal changes. ${ }^{44,45}$ Apicoronal changes are more evident in mul- 
Una variable importante en los implantes inmediatos postextracción y carga inmediata es la distancia mayor entre implante y la pared del alvéolo. En los casos donde esta distancia sea de $2 \mathrm{~mm}$ o menos, la oseointegración tiene lugar de forma adecuada. ${ }^{43} \mathrm{Si}$ la distancia es mayor de $2 \mathrm{~mm}$ se recomienda el relleno de ese espacio mediante algun tipo de biomaterial y por lo tanto se debe posponer la carga. Por otro lado en casos postextracción, se considera interesante trabajar mediante la osteotomía, $5 \mathrm{~mm}$ coronales al ápice del diente a extraer para conseguir una mayor estabilidad primaria.

\section{Calidad ósea}

Las variables anatómicas, que de forma más dramática afectan al pronóstico de los implantes a nivel de maxilar edéntulo, son la cantidad y la calidad de hueso de que disponemos. Según la clasificación de Misch, las zonas de hueso tipo IV serían zonas de riesgo de pérdida de implantes. ${ }^{18,61}$ Estos autores presentan una tasa de éxito del $66 \%$ de los implantes en zonas de hueso tipo IV y un $91 \%$ en el resto de las zonas (hueso tipo I, II o III). Bergqvist, ${ }^{25}$ obtiene un $71 \%$ de tasa de éxito en el maxilar superior en casos con hueso tipo III y IV.

\section{Biotipo gingival}

En casos de compromiso estético, el biotipo gingival delgado es menos favorable que el grueso en caso de afrontar una carga inmediata. En aquéllos, la reabsorción de la tabla vestibular provocaría mayor facilidad en relación con problemas estéticos. ${ }^{19}$

\section{Características del implante}

Las características del implante que favorecen la carga inmediata son las siguientes: implantes roscados y superficie rugosa. El grabado ácido y el arenado son los métodos elegidos por la mayoría de los autores. ${ }^{26}$ En cuanto a la longitud del implante, algunos autores describen fallos debidos a la utilización de implantes cortos, sobre todo cuando son colocados en zonas con hueso limitado. Se ha sugerido una longitud mínima para la realización de carga inmediata de $10 \mathrm{~mm} .22,24,62$ Sin embargo, Jaffin y cols. ${ }^{29}$ utilizan una longitud mínima de implante de $8 \mathrm{~mm}$ colocando entre 6 y 8 implantes en cada uno de los 34 maxilares atróficos que reconstruye con una tasa de éxito de $92,2 \%$ al año de seguimiento. En algunas publicaciones, ${ }^{26,63,64}$ utilizan un implante más ancho, cuando no se obtiene estabilidad primaria mediante el implante inicial. Los nuevos diseños de implantes (modificaciones de las espiras o modelos expansivos) han mejorado las perspectivas de la carga inmediata en ambos maxilares pero no han sido todavía cientificamente comparados con otros implantes de otros diseños en estudios en humanos realizados a largo plazo. ${ }^{65}$

\section{Torque}

Calandriello y cols, 66 indican como requerimiento, para la carga inmediata, un mínimo torque de inserción de $60 \mathrm{Ncm}$ para implan- tiple extraction sites. ${ }^{45-47}$ These changes are slightly greater in the molar region than in the premolar region, and in the mandible when compared to the maxilla. A large variety of factors can influence the dimensional changes in bone after dental extraction. Systemic factors can be included, in relation to the patient's previous state of health and smoking. With in the local factors, we can include the causes behind the extraction, the number and proximity of the extracted teeth and the condition of the alveolus before and after dental extraction. ${ }^{43}$ Follow-ups of between 1 and 4 years have not shown any significant differences with regard to radiographic changes in bone levels, in either implant areas where immediate loading was carried out, or other areas where conventional loading was carried out.48-52 The sockets with dehiscence defects may not have the potential for complete bone regeneration, and the risk of long term complications can increase if the implants are immediately loaded. 53

It has been demonstrated in various studies, that the survival rates of immediately loaded implants, after the extraction of teeth with root fractures, perforations or with a combination of endodontic and periodontic problems, is similar to that of implants placed in areas that have already healed. ${ }^{54-58}$ As always, the implants placed in areas where the tooth has been affected by chronic periodontitis, have been associated with slightly higher failure rates. 59,60 When implant placement is delayed following dental extraction, soft tissue will heal and increase in volume, which will permit adapting flaps in the future, and this will help to achieve good aesthetic results. Therefore, the period between dental and implant extraction will have advantages with regard to the amount of soft tissue achieved, but this will carry the risk of bone loss due to resorption. ${ }^{43}$

An important variable in immediate post extraction implants and in immediate loading, is the greater distance between the implant and the socket wall. In cases where this distance is $2 \mathrm{~mm}$ or less, osseointegration is adequate. ${ }^{43}$ If the distance is greater than $2 \mathrm{~mm}$, this space should be filled by means of some type of biomaterial, and loading should therefore be postponed. On the other hand, in postextraction cases, using an osteotomy $5 \mathrm{~cm}$ coronal to the apex of the tooth to be extracted, is considered of interest in order to achieve primary stability.

\section{Bone quality}

The anatomic variables, which affect implant prognosis in a more dramatic fashion, with regard to the edentulous maxilla, are the quantity and quality of bone that is available. According to Misch's classification, the areas of type IV bone are the areas with a risk of implant loss. 18,61 These authors have had an implant success rate of $66 \%$ in areas with type IV bone, and $91 \%$ in the remaining areas (type I, II or III). Bergqvist25 had a $71 \%$ success rate in the maxilla with type III and IV bone. 
tes unitarios, $45 \mathrm{Ncm}$ para implantes que soportan restauraciones de arcos parciales, y $32 \mathrm{Ncm}$ para restauraciones de arcos completos. Probablemente, el método más frecuente de evaluación de estabilidad es la opinión subjetiva del propio cirujano. ${ }^{35}$ Degidi y Piatelli, ${ }^{26}$ realizan un estudio consistente en un análisis comparativo, entre implantes sometidos a carga inmediata funcional y carga inmediata no funcional frente a un grupo control sometido a carga convencional. Estos autores mantienen que es necesario un torque mayor de $25 \mathrm{Ncm}$ y un cociente de estabilidad del implante (ISQ) mayor de 60 medido mediante frecuencia de resonancia (Resonance frequency, Osstell ${ }^{\circledR}$ ) como criterio de inclusión.

La estabilidad primaria del implante es un requisito fundamental en lacarga inmediata. Han sido sugeridos varios métodos de medida de la misma (torque e ISQ), pero es imposible comparar resultados y extraer conclusiones, acerca de cual es el más adecuado método de medida, para valorar este parámetro. ${ }^{23,24}$

\section{Número de implantes}

En cuanto a la carga inmediata de implantes que soportan prótesis fijas en maxilar superior edéntulo, la mayoría de los autores coinciden en lo siguiente: es necesario un mayor número de implantes en el maxilar que en la mandíbula para soportar de forma inmediata arcos completos. 5,10 El número medio de implantes en el maxilar superior es de 7,82 frente a los 4,54 del maxilar inferior. ${ }^{25-30}$ Por ejemplo, Bergkvist y cols, 25 colocan entre 5 y 7 implantes con un seguimiento de 1-2 años con una tasa de éxito del $98 \%$. Por lo tanto, en carga inmediata de maxilar superior, la experiencia dice que, cuando utilizamos de 6 a 8 implantes de superficie rugosa, la osteointegración ocurre de forma adecuada bajo situaciones de carga. No obstante, el número de implantes a utilizar viene determinado por otros factores: ${ }^{18}$

- La extensión de los planes protésicos

- La calidad de hueso disponible. A menor calidad de hueso sería conveniente incrementar el número de implantes

- La función estimada durante el periodo de carga

- Los condicionantes económicos.

El método "All on four" descrito por Maló, 65 para maxilares edéntulos, tiene la particularidad de utilizar solamente 4 implantes sobre los cuales se ancla una prótesis fija. Los dos implantes laterales se colocan con una angulación de 30 grados con respecto al plano oclusal, lo más posterior posible, y siguiendo la pared anterior del seno maxilar pero sin penetrar en el mismo. Tiene como objetivo una emergencia del implante lo más posterior posible y permitir una carga inmediata. En estos casos el autor defiende la utilización de cantilever.

Algunos autores, 28 han colocado implantes y han hecho carga inmediata de forma transmucosal (flapless surgery). En un estudio multicéntrico sobre 27 pacientes donde se utilizó una planificación virtual con la ayuda de la TC y obtención de una férula quirúrgica prefabricada a través de la cual se colocaban los implantes, se obtuvo un índice de éxito de 100\%.
Gingiva biotype

In cases of aesthetic compromise, a thin gingiva biotype is less favorable than thick, should immediate loading be undertaken. In the latter case, plate resorption would facilitate things with regard to aesthetic problems. ${ }^{19}$

\section{Implant characteristics}

Implant characteristics that favor immediate loading are the following: threaded implants with a rough surface: Acidetching and sand-blasting are the methods chosen by most authors. ${ }^{26}$ With regard to implant length, some authors describe the failures, due to the use of short implants, especially when placed in areas with limited bone. A minimum length of $10 \mathrm{~mm}$ for carrying out immediate loading has been suggested. 22,24,62 However, Jaffin and cols29 used an implant with a minimum length of $8 \mathrm{~mm}$ and they placed between 6 and 8 implants in each of the 34 atrophic maxillas that they reconstructed with a success rate of $92.2 \%$ after a follow-up of a year. In some publications ${ }^{26,63,64}$ a wider implant is used, when primary stability by means of the initial implant is not obtained. New implant designs (modification of spirals or expansive models) have improved the immediate loading perspectives in both jaws, but they have not been scientifically compared with the designs of other implants in long-term human studies. ${ }^{65}$

\section{Torque}

Calandriello and cols66 suggest, as an immediate loading requirement, a minimum insertion torque of $60 \mathrm{Ncm}$ for single implants, $45 \mathrm{Ncm}$ for implants supporting restorations or partial arches, and $32 \mathrm{Ncm}$ for restorations of complete arches. Probably, the most frequent method for evaluating stability is the subjective opinion of the surgeon himself. ${ }^{35}$ Degidi and Piatelli, ${ }^{26}$ carried out a study that consisted in a comparative analysis of implants subjected to immediate functional loading and immediate non-functional loading, versus a control group subjected to conventional loading. These authors maintain that a torque of more than $25 \mathrm{Ncm}$ is needed together with an implant stability quotient (ISQ) of more than 60, measured by means of frequency resonance (Resonance frequency, Osstell ${ }^{\circledR}$ ) as inclusion criteria.

Primary implant stability is a fundamental requirement in immediate loading. Various methods for measuring this have been suggested (torque and ISQ), but comparing results is impossible, as is extracting conclusions as to which is the more suitable measuring method for evaluating this parameter. 23,24

\section{Number of implants}

With regard to the immediate loading of implants supporting fixed prostheses in the edentulous maxilla, most 
Tabla 2. Estudios prospectivos en carga inmediata de edentulismo parcial

$\begin{array}{lccccc}\text { Autores } & \text { Superficie } & \begin{array}{c}\text { No pacientes/ } \\ \text { No implantes }\end{array} & \begin{array}{c}\text { Seguimiento } \\ \text { (años) }\end{array} & \text { Tasa de éxito } & \text { Protesis } \\ \text { Calandriello y cols (2005) } & \text { Ti Unite } & 11 / 26 & 1 & 100 & \text { Prótesis fija parcial } \\ \text { Degidi y cols (2005) } & \text { Friadent } & 4 / 20 & 7 & 90 & \text { Prótesis fija } \\ \text { Glauser y cols (2005) } & \text { Ti Unite } & 10 / 26 & 4 & 88,5 & \text { Prótesis fija parcial } \\ \text { Nikellis y cols } & \text { Southern implants } & 6 / 15 & 1-2 & 100 & \text { Prótesis fija parcial }\end{array}$

Table 2. Prospective studies in immediate loading of partially edentulous patients

\begin{tabular}{|c|c|c|c|c|c|}
\hline Authors & Surface & $\begin{array}{l}N^{o} \text { patients/ } \\
N^{o} \text { implants }\end{array}$ & $\begin{array}{l}\text { Follow-up } \\
\text { (years) }\end{array}$ & Success rate & Prosthesis \\
\hline Calandriello \& cols (2005) & Ti Unite & $11 / 26$ & 1 & 100 & Fixed partial prosthesis \\
\hline Degidi \& cols (2005) & Friadent & $4 / 20$ & 7 & 90 & Fixed partial prosthesis \\
\hline Glauser \& cols (2005) & Ti Unite & $10 / 26$ & 4 & 88,5 & Fixed partial prosthesis \\
\hline Nikellis \& cols & Southern implants & $6 / 15$ & $1-2$ & 100 & Fixed partial prosthesis \\
\hline
\end{tabular}

\section{Reconstrucciones parciales}

En algún estudio se aporta una evidencia científica limitada para el maxilar superior, que sugiere que las tasas de éxito razonable en carga inmediata, son limitadas a la región anterior. ${ }^{24}$ Sin embargo, en la tabla 2 se analizan los resultados de los artículos estudiados. $26,30,66,67$ En total se rehabilitaron 31 pacientes y se utilizaron 87 implantes. La tasa de éxito global es de $93,47 \%$. Se describieron prótesis parciales en la parte anterior de la arcada superior con una tasa de éxito de 93,55\%. Para la parte posterior del maxilar superior se obtiene una tasa de éxito de $92,78 \%$. No se hallaron diferencias significativas. En la parte posterior de la arcada superior la tasa de éxito para las superficies mecanizadas y rugosas fueron del 77,53 y del $96,15 \%$ respectivamente, mientras que no se detectaron diferencias significativas en la región anterior. Esto indicaría que las prótesis parciales en estas zonas donde la calidad del hueso es mala el rendimiento de las superficies texturizadas es significativamente mejor que el de las mecanizadas.

Cannizaro y Leone ${ }^{68}$ comparan la carga inmediata y la convencional alcanzando una tasa de éxito del $100 \%$ en los dos casos. En un estudio randomizado, ${ }^{32}$ la carga inmediata se comparaba con la carga temprana, alcanzando una tasa de éxito del $96,6 \%$ y del $96,3 \%$ respectivamente con un seguimiento de dos años.

En reconstrucciones completas y parciales más del $80 \%$ de los fracasos de los implantes en carga inmediata del maxilar superior se dieron durante los 6 primeros meses y el 97,1\% tuvo lugar dentro del primer año tras su colocación. ${ }^{69}$

\section{Reconstrucciones unitarias}

Hay dos estudios, 68,70 disponibles donde se comparan carga inmediata con carga convencional. Ericsson y cols, con un seguimiento de dos años, afirma, tener un índice de éxito del 81,2\% frente a un $10 \%$ comparando carga inmediata con carga con- authors are in agreement on the following: a greater number of implants are needed in the maxilla than in the mandible for supporting complete arches immediately. 5,10 The mean number of implants in the maxilla is 7.82 as opposed to 4.54 in the lower jaw. ${ }^{25-30}$ For example, Bergkvist and cols. ${ }^{25}$ placed between 5 and 7 implants with a 1-2 year follow-up and a success rate of $98 \%$. Therefore, in immediate loading of the maxilla, experience tells us that when 6 to 8 implants with a rough surface are used, there will be adequate osseointegration under loading conditions. Nevertheless, the number of implants that should be used is determined by other factors: 18

- Extension of prosthetic plans.

- Quality of available bone, the lower the quality of the bone, the more implants should be used.

- Estimated function during the loading period.

- Financial conditioning factors.

The "All on four," method described by Maló65 for edentulous maxillas, is unusual in that only 4 implants are used onto which a fixed prosthesis is anchored. Both lateral implants are placed as far back as possible at an angle of 30 degrees with regard to the occlusal plane, while following the anterior wall of the maxillary sinus but without penetrating it. The objective is for the implant to emerge as far back as possible to permit immediate loading. In these cases the author defends the use of a cantilever.

Some authors ${ }^{28}$ have placed implants with immediate loading using a transmucosal approach (flapless surgery). In a multicentric study with 27 patients in which virtual planning was used with the help of a CAT scan together with prefabricated surgical splints through which the implants were placed, a success rate of $100 \%$ was achieved. 
Tabla 3. Estudios prospectivos en carga inmediata de implantes unitarios en maxilar superior

$\begin{array}{lccccc}\text { Autores } & \text { Superficie } & \begin{array}{c}N^{\circ} \text { pacientes/ } \\ N^{0} \text { implantes }\end{array} & \begin{array}{c}\text { Seguimiento } \\ \text { (años) }\end{array} & \text { Tasa de éxito } & \text { Edad (Intervalo) } \\ \text { Glauser y cols (2005) } & \text { Ti Unite } & 12 / 12 & 4 & 100 & \text { ? } \\ \text { Cornelini y cols (2004) } & \text { Straumann } & 30 / 30 & 1 & 96,7 & 27-59 \\ \text { Nikellis y cols. (2004) } & \text { Southern implants } & 2 / 2 & 1-2 & 100 & 19-33 \\ \text { Proussaefs y cols (2004) } & \text { Replace } & 10 / 10 & 3 & 100 & 37-77 \\ \text { Kan y cols (2003) } & \text { Replace } & 35 / 35 & 1 & 100 & 18-65 \\ \text { Lorenzoni y cols (2003) } & \text { Frialit } & 12 / 12 & 1 & 100 & ? \\ \text { Andersen y cols (2002) } & \text { Strauman } & 8 / 8 & 5 & 100 & ? \\ \text { Proussaefs y cols (2002) } & \text { Replace } & 10 / 10 & 1 & 100 & 19-28 \\ \text { Hui y cols (2001) } & \text { Maquinado Branemark } & 24 / 24 & 1,2 & 100 & ? \\ \text { Wohrle y cols (1998) } & \text { Replace } & 14 / 14 & 0,75-3 & & ?\end{array}$

Table 3. Prospective studies in immediate loading of single implants in the maxilla

\begin{tabular}{|c|c|c|c|c|c|}
\hline Authors & Surface & $\begin{array}{l}N^{o} \text { patients/ } \\
N^{o} \text { implants }\end{array}$ & $\begin{array}{l}\text { Follow-up } \\
\text { (years) }\end{array}$ & Success rate & Age (interval) \\
\hline Glauser \& cols (2005) & Ti Unite & $12 / 12$ & 4 & 100 & ¿? \\
\hline Cornelini \& cols (2004) & Straumann & $30 / 30$ & 1 & 96,7 & $27-59$ \\
\hline Nikellis \& cols. (2004) & Southern implants & $2 / 2$ & $1-2$ & 100 & $19-33$ \\
\hline Proussaefs \& cols (2004) & Replace & $10 / 10$ & 3 & 100 & $37-77$ \\
\hline Kan \& cols (2003) & Replace & $35 / 35$ & 1 & 100 & $18-65$ \\
\hline Lorenzoni \& cols (2003) & Frialit & $12 / 12$ & 1 & 100 & $?$ \\
\hline Andersen \& cols (2002) & Strauman & $8 / 8$ & 5 & 100 & $17-28$ \\
\hline Proussaefs \& cols (2002) & Replace & $10 / 10$ & 1 & 100 & $?$ \\
\hline Hui \& cols (2001) & Machined Branemark & $24 / 24$ & 1,2 & 100 & $19-59$ \\
\hline Wohrle \& cols (1998) & Replace & $14 / 14$ & $0,75-3$ & 100 & $?$ \\
\hline
\end{tabular}

vencional. Sin embargo, hay una serie de estudios prospectivos (Tabla 3). ${ }^{30,67,71-78}$ Indican una tasa de éxito entre 96,7 a $100 \%$ con un seguimiento de 5 años. Incluso para el reemplazamiento de premolares había un índice de éxito de 100\%.72,76 En total 157 reconstrucciones unitarias en el maxilar superior de 157 pacientes. La tasa de éxito global fue del 96,19\%. Restauraciones inmediatas localizadas en la región estética (región anterior) obtienen una tasa de éxito de $96,96 \%$. Reconstrucciones en la región posterior del maxilar superior obtienen una tasa de éxito de 93,06\%. Para las reconstrucciones unitarias en régimen de carga inmediata no se halló ninguna diferencia significativa entre las tasas de superviviencia para los implantes de superficie mecanizada y rugosa tanto en la parte anterior como en la posterior de la arcada superior.

Para algún autor, ${ }^{79}$ los implantes unitarios, situados en la región posterior, tienen mayor susceptibilidad de ser sometidos a sobrecarga. Parece ser que el incremento de diámetro del implante puede ser una manera efectiva de incrementar la resistencia de los mismos. Un implante más fuerte no resuelve un problema de sobrecarga completamente, pero disminuye las consecuencias de la misma, en el punto más débil del sistema: el implante o en la superficie ósea de contacto. ${ }^{79}$

Hui, 77 propone un torque mínimo de 40-50 Ncm para reconstrucciones unitarias. Otros evitan contactos incisales. ${ }^{75}$ No hay en el momento actual estudios que comparen carga inmediata funcional y no funcional para reconstrucciones unitarias. ${ }^{80}$ Solo un estu-

\section{Partial reconstructions}

There is a study in which limited scientific evidence is put forward for the maxilla, which suggests that reasonable success rates in immediate loading are limited to the anterior region. ${ }^{24}$ However, in table 2, the results are analyzed of the articles studied.26,30,66,67 A total of 31 patients were rehabilitated and 87 implants were used. The global success rate was $93.47 \%$. Partial prostheses were used in the anterior portion of the upper arch with a success rate of 93.55\%. For the posterior part of the maxilla a success rate of $92.78 \%$ was achieved. Significant differences were not found. In the posterior part of the upper arch the success rate for machined and rough surfaces was 77.53 and $96.15 \%$ respectively, while no significant differences were detected in the anterior region. This indicates that when placing partial prostheses in areas with bad bone quality, the performance of textured surfaces is significantly higher than machined surfaces.

Cannizaro and Leone ${ }^{68}$ compared immediate and conventional loading, obtaining a success rate of $100 \%$ in both cases. In a randomized study, 32 immediate loading was compared with early loading and a success rate of $96.6 \%$ and $96.3 \%$ respectively was achieved with a follow-up of two years. 
dio demuestra la satisfacción estética de los pacientes con carga inmediata en reconstrucción unitaria. ${ }^{73}$

\section{Requerimientos protésicos}

Los conceptos protésicos que deben manejarse son simples y esenciales: ${ }^{19}$

- Que la carga inmediata suponga una clara ventaja para la calidad de vida del paciente.

- Control de los efectos biomecánicos de la restauración provisional (contactos oclusales, limitación de movimientos excursivos y de los efectos de un cantilever nunca deseable).

- Seguimiento de los mismos principios de la prótesis convencional (pasividad).

- Las restauraciones provisionales deben permanecer durante la curación de los tejidos blandos y óseos).

\section{Contraindicaciones}

La carga inmediata estaría contraindicada en aquellas situaciones donde no pueda obtenerse una estabilidad primaria adecuada por falta de cantidad o calidad ósea. El bruxismo es considerado por la mayoría de los autores como criterio de exclusión. ${ }^{63-66}$ Asimismo la infección puede ser considerada otra contraindicación. Otra contraindicación está marcada cuando los requerimientos estéticos del paciente necesitan de un procedimiento clásico (en dos tiempos). ${ }^{69}$

\section{Conclusiones}

La realización de carga inmediata y de prótesis fijas a nivel de maxilar superior, no está apoyada por suficientes datos, para considerar esta modalidad de tratamiento como algo rutinario, aunque los datos de resultados preliminares de que disponemos parece que son alentadores. La carga inmediata en maxilar superior es posible pero no hay un protocolo estandarizado en cuanto al número de implantes y tiempo de colocación de los mismos en relación con la exodoncia de piezas dentarias. El tratamiento con carga inmediata aporta al paciente satisfacción aunque no hay evidencia científica en relación al coste-efectividad de esta técnica.

Aunque existen estudios con años de seguimiento faltan datos en cuanto al seguimiento a largo plazo y los resultados estéticos de implantes inmediatos. Las nuevas técnicas (implantes no sumergidos y procedimiento sin necesidad de colgajos) necesitan evaluaciones adicionales.

\section{Bibliografía}

1. Ledermann PD. Stegprothetische versogung des zahnlosen unterkiefers mit hilfe von plasmabeschichteten titan- schaubenimplantaten. Dtsch Zahnarztl Z 1979;34:907-11.
In complete and partial reconstruction, more than $80 \%$ of implant failures in immediate loading of the maxilla took place during the first six months, and $97.1 \%$ took place in the first year after placement. 69

\section{Single tooth reconstruction}

There are two studies 68,70 available comparing immediate with conventional loading. Ericsson and cols, after a twoyear follow-up, claimed to have a success rate of $81.2 \%$ versus $100 \%$ when comparing immediate loading with conventional loading. However, there are a series of prospective studies (Table 3) $30,67,71-78$ that indicate a success rate of between 96.7 and $100 \%$ with a follow-up of 5 years. Even for premolar replacement, the success rate was 100\%.72,76 A total of 157 single teeth were reconstructed in the maxilla of 157 patients. The global success rate was $96.19 \%$. Immediate restoration located in the aesthetic region (anterior region) had a success rate of $96.96 \%$. Reconstruction in the posterior region of the maxilla had a success rate of 93.06\%. In single tooth implants with reconstruction of the immediate loading type, no significant difference was found in the survival rates of the implants with a machined versus rough surface in either the anterior or posterior area of the upper arch.

For some authors 79 single tooth implants that are situated in the posterior region are more susceptible to overloading. It would appear that increasing the diameter of the implant could be an effective manner of increasing resistance. A stronger implant does not resolve the problem of overloading completely, but it does lessen the consequences in the weakest point of the system: the implant or the contacting bone surface. ${ }^{79}$

Huip7 proposes a minimum torque of 40-50 Ncm for single tooth reconstructions. Others avoid incisal contact. ${ }^{75}$ Currently there are no studies that compare immediate functional and non-functional loading for single tooth reconstructions. ${ }^{80}$ Only one study demonstrates the aesthetic satisfaction of patients with immediate loading, single tooth implants. $^{73}$

\section{Prosthetic requirements}

The prosthetic concepts that should be kept in mind are simple and essential: 19

- Immediate loading represents a clear advantage with regard to the quality of life for the patient.

- The biomechanical effects of provisional restorations should be controlled (occlusal contact, limitation of excursion movements together with any undesirable cantilever effects).

- Follow-ups with the same principles as conventional prostheses (passivity).

- Provisional restorations should be kept in place while soft tissues and bone are healing. 
2. Branemark PI, Zarb G, Albretsson T. Tissue-integrated prostheses: osseointegration in clinical dentristy. Chicago: Quintessence, 1985;11-76.

3. Branemark PI, Hansson BO, Adell R, Breine U, Lindstom J, Hallen O, y cols. Osseointegrated implants in the treatment of the edentulous jaw. Experience from a 10 year period. Scand J Plast Reconstr Surg Suppl 1997;16:1-132.

4. Laney WR, Tolman DE, Keller EE. Dental implants: tissue-integrated prosthesis utilizing the osseointegration concept. Mayo Clin Proc 1986;61:91-7.

5. Chiapasco M. Early and inmediate restoration and loading of implants in completely edentulous patients. Int J Oral Maxillofac Implants 2004;19(Suppl):7691.

6. Sagara M, Akawaga Y, Nikau H, Tsuru $H$. The effects of early occlusal loading on one-stage titanium alloy implants in beagle dogs: A pilot study. J Prosthet Dent 1993;69:281-8.

7. Zubery $\mathrm{Y}$, Bichacho $\mathrm{N}$, Moses $\mathrm{O}, \mathrm{Tal} \mathrm{H}$. Inmediate loading of modular transitional implants: a histologic and histomorphometric study in dogs. Int J Periodontics Restorative Dent 1999;19:343-53.

8. Piattelli A, Corigliano M, Scarano A, Costigliola G, Paolantonino M. Inmediate loading of titanium-sprayed implants: an histologic analisis in monkeys. J Periodontol 1998;69:321-7.

9. Romanos GE, Toh CG, Siar CH, Swaminathan D. Histologic an histomorphometric evaluation of peri-implant bone subjected to inmediate loading: an experimental study with macaca fascicularis. Int J Oral Maxillofac Implants 2002;1 7:4451.

10. Nkenke E, Fenner M, Vairaktaris EG, Neukam FW, Troger MR. Inmediate versus delayed loading of dental implants in the maxillae of minipigs. Histomorphometrics analysis. Int J Oral Maxillofac Implants 2005;20:540-6.

11. Maniatopoulos C, Pilliar RM, Smith D. Threaded versus porous-surfaced designs for implant stabilization in bone-endodontic implant model. J Biomed Mater Res 1986;20:1309-33.

12. Pilliar RM, Lee GM, Maniatopoulos C. Observations on the effect of movement on bone ingrowth into porous-surfaced implants. Clin Orthop Relat Res 1986;208: 108-13.

13. Pilliar RM, Deporter D, Watson PA. Tissue-implant interface:Micromovment effects. En: Vincenzini P (ed). Materials in Clinical Applications: Proceedings of topical Symposium VIII on materials in clinical applications of the 8th CIMTEC world ceramic congress and forum on new materials, Florence, Italy, June 28 to July 4, 1994, vol 12, advances in science and technology. Faenza, Italy: Techna 1995:569-9.

14. Brunski JB. In vivo bone response to biomechanical loading at the bone dental implant interface. Adv Dent Res 1999;13:99-119.

15. Szmukler-Monkler S, Salama H, Reingewirtz Y, Dubruille JH. Timing of loading and effect of micromotion on bone dental implant interface: Rewiew of experimental literature. J Biomed Mater Res 1998;43: 192-203.

16. Jaffin RA, Kumar A, Berman CL. Inmediate loading of dental implants in the completely edentulous maxila: a clinical report. Int Oral Maxillofac Implants 2004; 19:721-30.

17. Truhlar RS, Orestein IH, Morris HF, Ochi S, Distribution of bone quality in patients receiving endosseus dental implants. J Oral Maxillofac Surg 1997;55(Suppl 5):3845.

18. Cooper L, De Kok, Reside G, Pungpapong P, Rojas- Vizcaya F. Inmediate fixed restoration of the edentulous maxilla after implant placement. / Oral Maxillofac Surg 2005;63(suppl 2):97-110.

19. Tarnow DP, Emtiaz S, Classi A. Inmediate loading of threaded implants at stage 1 surgery in edentulous arches. Ten consecutive case reports with 1 to 5 year data. Int J Oral Maxillofac Inplants 1997;12:319-24.

20. Ganeles ], Rosenberg MM, Holt RL, Reichman LH. Inmediate loading of implants

\section{Contraindications}

Immediate loading is contraindicated in those situations in which adequate primary stability cannot be obtained because of a lack of bone quality. Most authors consider bruxism as an exclusion criteria. ${ }^{63-66}$ Furthermore, infection can be considered another contraindication. Another contraindication would be if the aesthetic needs of the patient require a classical procedure (two stage). ${ }^{69}$

\section{Conclusions}

Carrying out immediate loading and fixed prostheses in the maxilla is not supported by sufficient data that enable viewing this treatment modality as something routine, although the data concerning the preliminary results that are at our disposal is encouraging. Immediate loading in the maxilla is possible, but there is no standard protocol with regard to the number of implants and placement times with regard to tooth extractions. Treatment involving immediate loading provides satisfaction to the patient although there is no scientific evidence with regard to the effective cost of this technique.

Although there are studies with follow-ups of several years, there is a shortage of data with regard to long-term follow-ups and the aesthetic results of immediate implants. New techniques (non-submerged implants and flapless procedures) require additional evaluation. 
with fixed restorations in the completely edentulous mandible: Report of 27 patients from a private practice. Int J Oral Maxillofac Implants $2001 ; 16: 418-26$.

21. Aparicio C, Rangert B, Sennerby L. Inmediate / early loading of dental implants: A report from the Sociedad Española de Implantes World Congress Consensus Metting in Barcelona, Spain, 2002. Clin Implant Dent Relat Res 2003;5:57-60.

22. Uribe R, Peñarrocha M, Balaguer J, Fulgueiras N. Inmediate loading in implantology. Med Oral Patol Oral Cir Bucal 2005;10(Suppl 2):E143-53.

23. Morton D, Jaffin R, Weber H. Inmediate restoration and loading of dental implants: clinical considerations and protocols. Int J Oral.

24. Attard N, Zarb G. Inmediate and early implant loading protocols: A literature review of clinical studies. J Prosthet Dent 2005;94:242-58.

25. Bergkvist G., Salholm S., Karlsson U., Nilner K, Lindh C. Inmediate loaded implants supporting fixed prosthesis in the edentulous maxilla: a preliminary clinical and radiological report. Int J Oral Maxillofac Implants 2005;20:399-405.

26. Degidi M, Piattelli A. Comparative análisis study of 702 dental implants subjected to inmediate funcional loading and inmediate non funcional loading to tradicional healing periods with a follow up of up to 24 months. Int J Oral Maxillofac Implants 2005;20:99-107.

27. Ibañez JC, Tahhan MJ, Zamar JA. Inmediate occlusal loading of double etched surface titanium implants in 41 consecutive full arch cases in mandible and maxilla: 6 to 74 months results. J Periodontol 2005;76: 1972-81.

28. van Steenberghe D, Glauser R, Blomback U. A computed tomographic scan derived customized surgical templante and fixed prosthesis for flapless surgery and inmediate loading of implants in fully edentulous maxillae: A prospective multicenter study. Clin Implant Dent Relat Res 2005;7(suppl 1):S111-S120.

29. Jaffin RA, Kumar A, Berman CL. Inmediate loading of dental implants in the completely edentulous maxilla: a clinical report. Int J Oral MaxiIlofac Implants 2004;19: 21-730.

30. Nikellis I, Levi A, Nicolopoulos C. Inmediate loading of 190 endosseous dental implants: a prospective observational study of 40 partient treatments with up to 2 year data. Int J Oral Maxillofac Implants 2004;19:116-23.

32. Testori T, Del Fabbro, M, Szmukler-moncler S, Francetti L, Weinstein RL. Inmediate occlusal loading of implants in the completely edentulous mandible. Int J Oral Maxillofac Implants 2003;18:544-51.

33. Norton MR. A short-term clinical evaluation of inmediately restored maxillary TiOblast single-tooth implants. Int Oral Maxillofac Implants 2004;19:274-81.

34. Grunder U. Inmediate funcional loading of inmediate implants in edentolous arches: two-year results. Int J Periodontics Restorative Dent 2001;21:545-51.

36. Van de Bogaerde L, Pedretti g, Dellacasa P, Mozzati M, Rangert B. Early function of splinted implants in maxilla and posterior mandible using Branemark System, machined surface implants: an 18 month prospective clinical multicenter study. Clin Implant Dent Relat Res 2003;5:21-9.

37. Ericsson I, Nilson H, Nilner K. Inmediate funcional loading of Branemark single tooth implants. A 5 year clinical follow up. Applied Osseointegration Research 2001;2:12-7.

38. Colomina LE. Inmediate loading of implant-fixed mandibular prostheses: prospective 18 month follow up clinical study preliminary report. Implant Dent 2001;10:23-9.
39. Engquist B, Astrand P, Anzen B, Dahlgren S, Engquist E, Feldman H, y cols. Simplified methods of implants treatment in edentulous lower jaw. A controled prospective study. Part I: one stage versus two stage surgery. Clin implant Dent relat Res 2002;4:93-103.

40. Huebsch RF, Hansen LS. A histopathologic study of extraction wounds in dogs. Oral Surg Oral Med Pathol 1969;282:187-96.

41. Otha Y. Comparative changes in microvasculature and bone during healing of implant and extraction sites. J Oral Implantol 1993;193:184-98.

42. Bodner L, Dayan D, Rothchild D, Hammel I. Extraction wound healing in desalivated rats. J Oral Pathol Med 1991;20:176-8.

43. Chen S, Wilson T, Hammerle C. Inmediate or early placement of implants following tooth extraction: review of biologic basis, clinical procedures and outcomes. Int J Oral Maxillofac Implants 2004;19(suppl): $12-25$.

44. Johnson K. A study of the dimensional changes occurring in the maxiIla after tooth extraction. Part I: normal healing. Aust Dent / 1963;8:42834.

45. Johnson K. A study of the dimensional changes ocurring in the maxiIla following tooth extraction. Aust Dent J 1969:14;241-4.

46. Schoropp L, Wenzel A, Kostopoulos L, Karring T. Bone healing and soft tissue contour changes followwing single tooth extraction: $A$ clinical and radiographic 12 month prospective study. Int J Periodontics Restorative Dent 2003;23:313-23.

47. Lam RV. Contour changes of the alveolar processes following extraction. J Prosthet Dent 1960;10:25-32.

48. Watzek G, Haider R, Mensdorf N, Haas R. Inmediate and delayed implantation for complete restoration of the jaw following extraction of all residual dent: A retrospective study comparing different types of serial inmediate implantation. Int / Oral Maxillofac Implants 1995; 105:561-7.

49. Mensdorf N, Haas R, Mailath G, Watzek G. The inmediate implant: A retrospective study comparing the different types of implantation. Int J Oral Maxillofac Implants 1994;9:571-8.

50. Gomez-Roman G, Schulte W, Hoedt B, Axman D. The frialt - 2 implant system: Five year clinical experience in single tooth and inmediately postextraction applications. Int J Oral Maxillofac Implants 1997;123:299309.

51. Yukna RA. Clincal comparison of hydroxyapatite-coated titanium dental implants placed in fresh extraction sockets and healed sites. J Periodontol 1991;62:468-72.

52. Bragger U, Hammerle CHF, Lang NP. Inmediate transmucosal implants using the priciple of guided tissue regeneration. (II) A cross sectional study compring the clinical outcome 1 year after inmediate to standard implant placement. Clin Oral Implant Res 1996;7:268-76.

53. Wilson TG, Weber HP. Classification of and therapy for areas of deficient bony housing prior to dental implant placement. Int J Periodontics Restorative Dent 1993;13:451-9.

54. Pecora G, Andreana S, Cobani U, De Leonardis D, Schiferle RE. New directions in surgical endodontics: inmediate implatation into an extraction socket. J Endod 1996;223:135-9.

55. Novaes AB Jr, Novaes AB. Inmediate implants placed into infected sites: A clinical report. Int J Oral Maxillofac Implants 1995;10:609-13.

56. Nikellis I, Levi A, Nicolopoulos C. Inmediate loading of 190 endosseus dental implants: a prospective observational study of 40 patient treatments with up to 2 year data. Int / Oral Maxillofac Implants 2004;19:116-23. 
57. Novaes AB, Vidigal GM, Novaes AB, Grisi MFM, Polloni S, Rosa A. Inmediate implants placed into infected sites: a histomorphometric study in dogs. Int J Oral Maxillofac Implants 1998;13:422-7.

58. Novaes AB Jr, Marcaccini AM, Souza SL, Taba M, Grisi MF. Inmediate placement of implants into periodontally infected sites in dogs: a histomorphometrics study of bone - implant contact. Int J Oral MaxiIlofac Implants 2003;183:391-8.

59. Rosenquist B, Grenthe B. Inmediate placement of implants into extraction sockets: Implant survival. Int J Oral Maxillofac Implants 1996;112: 205-9.

60. Polizzi G, Grunder U, Goene R, et al. Inmediate and delayed implant placement into extraction sockets: A 5 year report. Clin Implant Dent Relat Res 2000;22:93-9.

61. Lekholm U, Zarb G. Patient selection and preparation. In: Branemark PI, Zarb G, Albrektsson T (eds). Tissue - integrated prostheses: osseointegration in clinical dentistry. Chicago: Quintessence 1985;199209.

62. Nikellis I, Levi A, Nicopoulos C. Inmediate loading of 190 dental implants: a prospecitve observational study of 40 patient treatments with up to 2 year data. Int J Oral Maxillofac Implants 2004;19:116-23.

63. Hourichi K, Uchida H, Yamamoto K, Sugimura M. Inmediate loading of Branemark system implants following placement in edentulous patiens: a clinical report. Int J Oral Maxillofac Implants 2000;15:824-39.

64. De Bruyn H, Collaert B. Early loading of machined surface Branemark implants in completely edentulous mandibles. Healed bone versus fresh extraction sites. Clin Implant Dent Relat Res 2002;4:136-42.

65. Maló P, Rangert B, Mech Eng, Nobre M. "All-on-four" Inmediate Function Concept with Branemark system implants for completely Edentulous Mandibles: a retrospective clinical study. Clin Implant Dent Relat Res 2003;5(suppl 1):2-9.

66. Calandriello R., Tomatis M. Simplified treatment of the atrophic posterior maxilla via inmediate/early function and tilted implants: a prospective 1-year clinical study. Clin Implant Dent 2005;(Supp 7):1-7.

67. Glauser R, Ruhstaller P, Windisch S, Zembic A, Lundgren A, Gottlow J, Hammerle $\mathrm{CH}$. Inmediate occlusal loading of Bränemark System Ti Unite implants placed predominantly in soft bone: a 4 year results of a prospective clinical study. Clin Implant Dent Relat Res 2005;7(Suppl I):S52-S 59).

68. Cannizzaro G., Leone S. Restoration of partially edentulous patients using dental implants with a microtexturized surface: a prospective comparison of delayed and inmediate full occlusal loading. Int J Oral Maxillofac Implants 2003; 18: 512-22.

69. Del Fabbro M, Testori T, Francetti L, Taschieri S, Weinstein R. Revisión sistemática de la tasa de implantes dentales cargados de forma inmediata. Int J Periodontics Restorative Dent 2006;26:249-63.

70. Ericsson I, Nilson H, Lindht T. Inmediate functional loading of Branemark single tooth implants. An 18 months clinical pilot follow-up study. Clin Oral Implant Res 2000;11:26-33.

71. Cornelini R, Cangini F, Covani U, Barone A. Inmediate restoration of single-tooth implants in mandibular molar sites: a 12 month preliminary report. Int J Oral Maxillofac Implant 2004;19:855-60.

72. Proussaefs P, Lozada J. Inmediate loading of hydroxiapatite coated implants in the maxillary premolar area: a 3-year results of pilot study. J Prosthet Dent 2004; 91:228-33.

73. Kan JY, Rungcharassaeng K. Inmediate placement and provisionalization of maxillary anterior single implants: a surgical and prosthodontic rationale. Pract Periodontics Aesthet Dent 2000;12:467-74.

74. Lorenzoni M, Pertl C, Zhang K, Winner G. Inmediate loading of single tooth implants in the anterior maxilla. Clin Oral Implant Res 2003;14: 180-7.

75. Andersen E, Haanaes HR, Knutsen BM. Inmediate loading of single tooth ITI implants in the anterior maxilla: a prospective 5-year pilot study. Clin Oral Implants Res 2002;13:281-7.

76. Proussaefs P, Kan J, Lozada J, Kleinman A. Effects of immediate loading with threaded hydroxiapatite coated root form implants on single premolar replacements: a preliminary report. Int J Oral Maxillofac Implant 2002; 17:567-72.

77. Hui E, Chow J, Li D, Liu J, Law H. Inmediate provisional for single tooth implant replacement with Branemark system: preliminary report. Clin Implant Dent Relat Res 2001;3:79-86.

78. Wohrle PS. Single tooth replacement in the aesthetic zone with inmediate provisionalization: fourteen consecutive case reports. Pract periodontics Aesthet Dent 1998;10:1107-14.

79. Abboud M, Koeck B, Stark H, Wahl G, Paillon R. Imediate loading of single tooth inplants in the posterior region. Int J Oral Maxillofac Implants 2005;20:61-8.

80. Nkenke E., Fenner M. Indications for inmediate loading of implants and implant success. Clin Oral Impl Res 2006;17(Suppl 2):19-34. 